\title{
Role of Agroforestry Practices in Changing Rural Livelihood Economy: Case study of Dhaibung VDC of Rasuwa District
}

\author{
Naba Raj Pandit ${ }^{1}$, Deepak Gautam and Sharada Adhikari \\ Corresponding Author: Naba Raj Pandit \\ E-mail: navraj20@gmail.com
}

\begin{abstract}
:
This paper is part of the case study on "Socio-economic development of rural people through Agroforestry system in Rasuwa District of Nepal" surveyed during 2008. With the aim to assess the contribution of agro forestry to household economy of rural people, a study was conducted at Dhaibung VDC of Rasuwa district as agro forestry system creates employment and livelihood opportunity to the majority of the rural dwellers. Comparative study was done between agro forestry and non-agro forestry system village based on the project in terms of financial benefits and incentives received by respondents. Findings from the study revealed that agro forestry system practiced in project area; gross income and net income analysis in project village $(\mathrm{PV})$ are more profitable than control village $(\mathrm{CV})$ farms. Income from sale of livestock, fruits, milk and milk products was higher in project village as compared to control village whereas income from public services, wage labour was somehow same. The integration of agroforestry into existing farming system is the strongest driver to meet the food sufficiency of rural resident for longer months and ensure food security sustainably in the study area.
\end{abstract}

Key Words: Agro-forestry, Upland/lowland, Fodder, Livestock, Socio-economic development

\section{Introduction}

Trees have been raised on farmlands in Nepal since earliest times. Planting of trees on farms is now a traditional practice under which people plant trees for meeting their requirements of fuel, fodder, timber and fruit. Often trees are also raised on farmlands, in association with agricultural crops which is known as agro-forestry may be defined as the concurrent use of the land for agriculture, forestry, horticulture and for raising livestock. The dominant farming systems also vary according to the physiographic regions. The middle hills consist of mixed, subsistence and multidisciplinary, which is heavily dependent on forest resources (Neupane, 2000). Agro forestry is the land use science which deals with the interaction between trees and crops, and of both with animals in the same unit of land (Wood, 1990).

${ }^{1}$ Program coordinator, Nepal Agroforestry Foundation 
Sanchez (1989) addressed sustainability in terms of maintenance of soil organic matters and nutrient recycling in Agroforestry systems. Agroforestry systems are generally perceived to be sustainable and to enhance soil properties.

The forest, livestock and crop are the subsystems of the hill farming systems. Hill economy has remained self-sustaining for a long time owing to low population density, good forest cover and grazing areas, low number of livestock, relatively better soil fertility, higher per capita cultivated land and terraced cultivation. Within the forest sub-system, fuel wood is very important component. The annual estimated consumption of traditional fuel is 11.3 million metre cube of which dung and farm residues supply 28 percent 18 percent in Terai and hills respectively. Overall, in Nepal $80 \%$ of domestic and industrial energy consumption is supplied through fuel wood, largely from natural forest, which is being depleted at an increasing and unsustainable manner (Pandit et al., 2007). The annual estimated consumption of traditional fuel is 11.3 million metre cube of which dung and farm residues supply 28 percent in the Terai and 18 percent in the hills. Of the total fuel wood supply, 14 percent in the Terai and 33 percent in the hills obtained from the private wood lots. (Dhakal, 2008)

The deforestation rate is higher due to increased population and fast growing timber market, the high demand of fuel wood and timber including NTFPs, which resulted in severe forest degradation, land degradation and natural ecosystem imbalances (Pandit, 1994). Fodder is supplied from both the farm and off farm sources; more than 50 percent of the total fodder supply comes from forest. Crop production depends on both livestock and forests, imbalances in any component can bring changes in the whole farming system. Moreover, tree crop could play a role in diversifying farm production, promoting soil stability and ameliorating the microclimate, while maintaining an acceptable stock carrying capacity (Tustin et al., 1979). Agro forestry based system in hills has contributed to the development of local economy. However, there are very few or no studies done in this sub-sector in the past. In terms of the land under cultivation, the farmlands fall into two broad categories, the bari (un irrigated upland) and khet (irrigated lowland paddy fields). Another type of land, which has special significance to agro forestry, is called kharbari, which is not used for crop production but used to grow thatching grass khar (Typha angustata) and other species of fodder, fuel wood, timber and grasses.

\section{Methodology}

\section{Selection of the survey site}

Dhaibung (Jibjibe nilkantha) VDC of Rasuwa district was selected purposively for this study. Following criteria were taken into account while selecting the area: i) Accessibility to conduct the research and ii) Researchers previous background knowledge about the study districts. 30 household of Dhaibung VDC where agro forestry system is being adopted and another 30 household of next village of same VDC where agro forestry system is not 
practiced was surveyed. The profitability (socio economic status) of the farmers with and without agro forestry system adopted in this same VDC was compared.

\section{Survey method and analysis of data}

The study has adopted a multipronged approach to collect relevant information. Both qualitative and quantitative data were collected. Quantitative data were gathered through a household survey using a structured questionnaire. Questionnaire survey method was employed to collect the necessary information from the respondents for which questionnaire was pre-tested, modified, and standardized. Questionnaires were administered to a random sample of 60 households in Dhaibung VDC areas. The questionnaire comprised the respondent's occupation, involvement in agriculture, form of involvement in agriculture, and availability, status, season and trade of agro forestry products. Qualitative information was assembled via Focal group discussion (FGDs) and Key informant interview (KII) with structured checklist. FGDs were undertaken in each study zone with community sub-groups including women and ethnic/caste minorities using a variety of participatory techniques. KII was operated with key stakeholders of the community, person of NGO/CBO's, traders of the community etc.

Collected data were coded and analyzed by using SPSS computer software package. T-test was operated as the sample size was small (30 HH each from CV and PV). Descriptive statistics were used as per need.

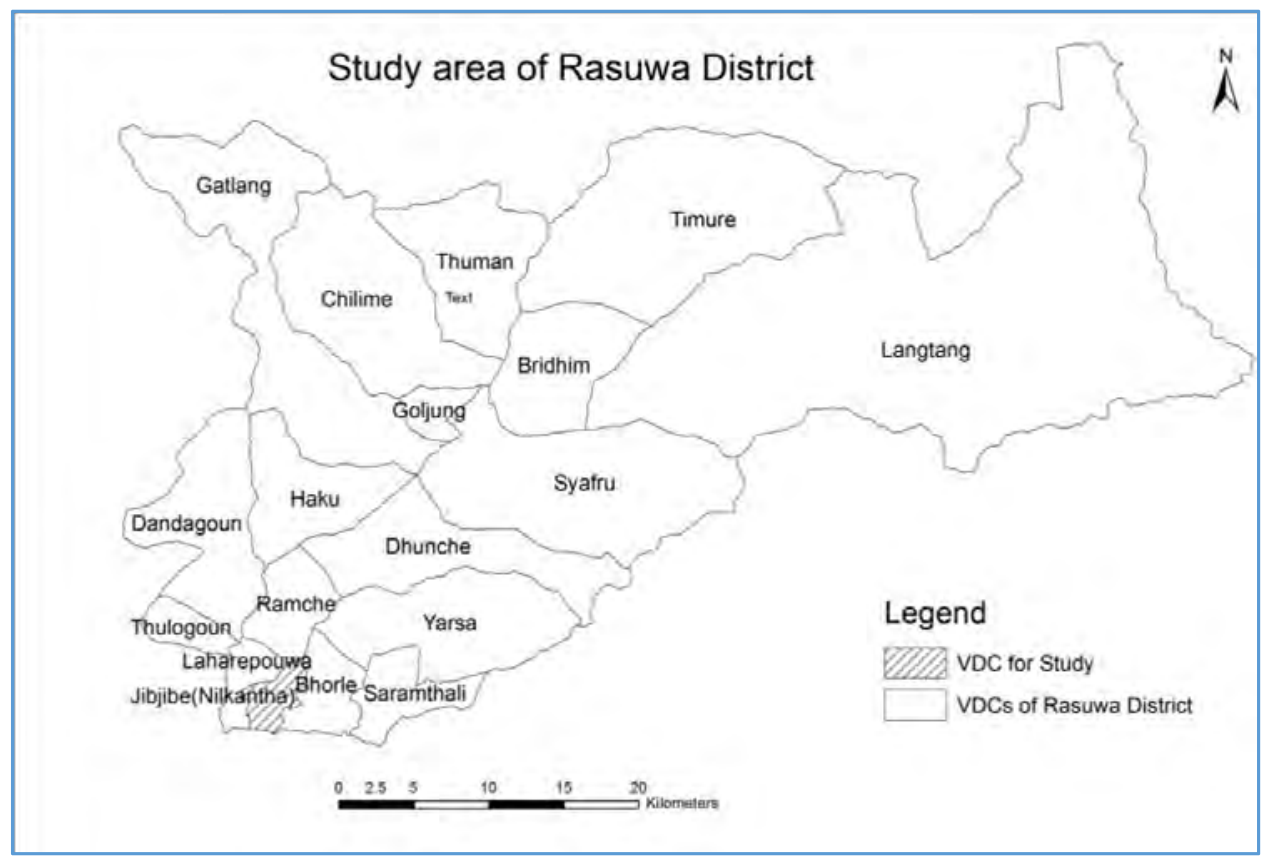

Figure 1: Study area 


\section{Results and Discussion}

\section{Educational status of villages}

Literacy rate between these two villages varies significantly; $82 \%$ male and $73 \%$ female were literate in project village and likewise $62 \%$ male and $49 \%$ female in control village. Study revealed that the number of male literacy was higher both in project and control village. Moreover, literacy rate of project village including both male and female was higher as compared to control village. Thus, the results divulged that there was significant difference in literacy rate of PV and CV household in the study area. Better income through agroforestry (AF) practices in their private farmland is one of the major pulling income factors of PV farmers to enrol their children in primary and high school.

Table 1: Literacy rate of household members (PV and CV)

\begin{tabular}{|l|l|l|l|l|}
\hline \multirow{2}{*}{ Village } & \multicolumn{2}{c|}{ Literate(numbers) } & \multicolumn{2}{c|}{ Illiterate(numbers) } \\
\cline { 2 - 5 } & \multicolumn{1}{|c|}{ Male } & \multicolumn{1}{c|}{ Female } & \multicolumn{1}{c|}{ Male } & \multicolumn{1}{c|}{ Female } \\
\hline \multirow{2}{*}{ Project village (PV) } & 2.26 & 1.80 & .33 & .66 \\
\cline { 2 - 5 } & $68(82 \%)^{* *}$ & $54(73 \%)$ & $10(12 \%)$ & $20(27 \%)$ \\
\hline Control village (CV) & 1.6 & 1.16 & .93 & 1.13 \\
\cline { 2 - 6 } & $50(62 \%)^{* * *}$ & $35(49 \%)$ & $28(35 \%)$ & $34(47 \%)$ \\
\hline \multirow{2}{*}{ Total } & $\mathbf{1 . 9 6}$ & $\mathbf{1 . 4 8}$ & $\mathbf{. 6 3}$ & $\mathbf{. 9 0}$ \\
\cline { 2 - 6 } & $\mathbf{1 1 8}$ & $\mathbf{8 9}$ & $\mathbf{3 8}$ & $\mathbf{5 4}$ \\
\hline
\end{tabular}

Source: Field survey, 2008

Note: figure inside parenthesis is percentage

** Significant at $95 \%$ confidence level; *** Significant at $99 \%$ confidence level

\section{Respondent Occupation}

About 73\% (22 respondents) were engaged in agriculture in PV and 60\% (18 respondents) in control village. Only $27 \%$ and $40 \% \%$ respondents from project and control village respectively deviated from agriculture as their main occupation.

Table 2: Employment status of respondents in the study area

\begin{tabular}{|l|l|l|l|l|}
\hline \multirow{7}{*}{ Village } & $\begin{array}{c}\text { Respondent } \\
\text { occupation } \\
\text { (number's) }\end{array}$ & \multicolumn{1}{|c|}{ Female } & Male & Female \\
\cline { 2 - 5 } & Agriculture & \multicolumn{1}{|c|}{ Service } & \multicolumn{1}{|c|}{ Labour } & \multicolumn{1}{c|}{ Total } \\
\hline Project village (PV) & $22(73)$ & $3(10)$ & $5(17)$ & $30(100)$ \\
\hline Control village (CV) & $18(60)$ & $5(17)$ & $7(23)$ & $30(100)$ \\
\hline Total & $\mathbf{4 0 ( 6 7 )}$ & $\mathbf{8 ( 1 3 )}$ & $\mathbf{1 2 ( 2 0 )}$ & $\mathbf{6 0 ( 1 0 0 )}$ \\
\hline
\end{tabular}




\section{Land Holding Size of Villages}

Average household of the project village holds 2 ropani of pasture land (kharbari) whereas that of control village occupied 1.2 ropani of kharbari. Lowlands generally irrigated in summer. Farmers grow rice as dominant crop in lowland. Generally, rice followed by wheat and maize in lowlands. Landholding size of project village and control village varied significantly. Average irrigated low land (khet) size was greater in CV (5.8 ropani) compared to PV (2.7 ropani) whereas un-irrigated upland land (pakho) was more in project village as shown in the table 3 below. Thus, agroforestry species (fodder, grass, fruits) were cultivated in upland (pakho) to greater extent in project village.

Table 3: Land size of PV and CV

\begin{tabular}{|l|l|l|l|l|l|}
\hline Village & \multicolumn{1}{|c|}{ Low land } & \multicolumn{1}{|c|}{ Upland } & Pasture & Garden & Total \\
\hline \multicolumn{5}{|l|}{ Ropani } \\
\hline$C V$ & 5.83 & 3.00 & 1.23 & .70 & 10.76 \\
\hline$P V$ & 2.70 & 4.66 & 2.01 & .83 & 10.2 \\
\hline
\end{tabular}

Source: Field survey, 2008

Note: $\mathrm{PV}=$ project village $\mathrm{CV}=$ control village

20 ropani $=1$ hectare

\section{Land Use Pattern}

Annually three different cereal crops were cultivated on irrigated land; rice as kharif crops, wheat as rabi crops and maize as said crops sequentially as shown in the table 4 below.

Average net sown area of lowland (khet) and upland (pakho) in PV was 2.7 ropani and 4.7 ropani respectively. Likewise, PV holds 8.1 ropani and 8.9 ropani gross sown area of khet and pakho respectively. Similarly average net sown area of khet and pakho was 5.8 and 3 ropani and gross sown area was 28.5 and 6 ropani respectively in control village. Study revealed that low land (khet) size was much higher in CV and farmers are motivated in cultivating cereal crops rather than undertaking Agroforestry (AF) practices in existing farming system. Also as the fodder trees cultivation has shown decrement in yield of crops, CV farmers are not intended to adopt AF practices in their respective farmland (low land and upland) and are enjoying sole cropping of seasonal crops.

Table 4: Net and gross sown area of crops

\begin{tabular}{|l|l|l|l|l|l|l|}
\hline Village & $\begin{array}{c}\text { Landholdings } \\
\text { type }\end{array}$ & $\begin{array}{c}\text { Kharif } \\
\text { crops }\end{array}$ & $\begin{array}{c}\text { Rabi } \\
\text { crops }\end{array}$ & $\begin{array}{c}\text { Zaid } \\
\text { crops }\end{array}$ & $\begin{array}{c}\text { Average } \\
\text { Net sown } \\
\text { area(ropani) }\end{array}$ & $\begin{array}{c}\text { Average Gross } \\
\text { sown area } \\
\text { (ropani) }\end{array}$ \\
\hline \multirow{2}{*}{$\begin{array}{l}\text { project } \\
\text { village }\end{array}$} & Khet & Rice & Wheat & Maize & 2.7 & 8.1 \\
\cline { 2 - 7 } & Pakho & Millet & & Maize & 4.7 & 8.9 \\
\hline $\begin{array}{l}\text { Control } \\
\text { village }\end{array}$ & Khet & Rice & Wheat & Maize & 5.8 & 28.5 \\
\cline { 2 - 7 } & Pakho & Millet & & Maize & 3 & 6 \\
\hline
\end{tabular}




\section{Food Sufficiency of Villages}

Food sufficiency was measured counting the support from own farm produces and purchasing with other cash income generated from the sale of household level farm produces. $34 \%$ of PV household meets their food requirement for nine and more months which in case of CV was only $20 \%$. Attempts were made how or which sources of income complimented the food deficit. Income derived from AF products leads in increased purchasing power for food and other daily items in PV household compared to CV household in the study area.

Table 5: Food sufficiency of Project Village and Control Village

\begin{tabular}{|l|l|l|l|}
\hline \multirow{2}{*}{ Village } & \multicolumn{3}{|c|}{ Food sufficiency level } \\
\cline { 2 - 4 } & \multicolumn{1}{|c|}{ For three months } & \multicolumn{1}{|c|}{ For six months } & $\begin{array}{c}\text { For 9 months and } \\
\text { more }\end{array}$ \\
\hline Project Village & $4(13)$ & $16(53)$ & $10(34)$ \\
\hline Control Village & $7(23)$ & $17(57)$ & $6(20)$ \\
\hline
\end{tabular}

Source: Household Survey, 2008

\section{Crop Yield in PV and CV farms}

Average yields of major cereal crops drastically varied among PV and CV household farm. The study showed that tree-crop interaction significantly decreases the yield of crops as shown in table 6 below. Total Average yield of cereal crops grown by PV and CV was 10.57 and 20.9 (muri/ropani/ per year) respectively. Cereal crops yield was almost double in CV compared with PV. It can be concluded that, tree-crop interaction results in lower yield of farm crops but has many other social, economic and environmental benefits which hold more income than sole cropping pattern. Due to shading effect and rainfall droplets from broad leaved fodder trees (damage grains), crop yield was lower to greater extent in PV farm. However, various study and research showed that nutrient recycling and soil fertility of the land increases with tree- crop interaction especially with leguminous trees thus increasing productivity of land.

Table 6: Crop Yield "with and without" tree-crop interaction

\begin{tabular}{|l|l|l|}
\hline \multirow{2}{*}{ Crop } & \multicolumn{2}{c|}{ Average yield (muri per ropani) } \\
\cline { 2 - 3 } & \multicolumn{1}{|c|}{ Yield “with” trees(PV) } & \multicolumn{1}{c|}{ Yield “without” trees(CV) } \\
\hline Maize & 3.7 & $6.4^{*}$ \\
\hline Millet & 2.27 & 1.5 \\
\hline Rice & 3.6 & $9.3 * *$ \\
\hline Wheat & 1 & 3.7 \\
\hline Total & $\mathbf{1 0 . 5 7}$ & $\mathbf{2 0 . 9}$ \\
\hline
\end{tabular}

Source: household survey 2008

Note: $*_{\mathrm{t}}$ is significantly different at 0.01 level and $* *_{\mathrm{t}}$ is significantly different at 0.05 level

1 hectare $=19.65$ ropani $\sim 20$ ropani, 1 muri $=\sim 72 \mathrm{~kg}$ 


\section{Livestock Size}

Average HH large cattle (buffalo \& cow) size was bigger in PV and reverse is the case for small animals (chicken \& ducks). Livestock number was greater in PV as compared to that of CV except in case of chickens. Research study concluded that the availability and promotion of fodder trees in PV had replaced small animal (chicken) with large animal (buffalo and cattle) as shown in the table 7 below.

Table 7: Livestock number by village

\begin{tabular}{|l|l|l|l|l|l|l|l|}
\hline Village & $\begin{array}{c}\text { Buff } \\
\text { (no) }\end{array}$ & $\begin{array}{c}\text { Buff calves } \\
\text { (no) }\end{array}$ & $\begin{array}{c}\text { Male } \\
\text { cattle(no) }\end{array}$ & $\begin{array}{c}\text { Cattle } \\
\text { (no) }\end{array}$ & $\begin{array}{c}\text { Cattle } \\
\text { calves(no) }\end{array}$ & $\begin{array}{c}\text { Goat } \\
\text { (no) }\end{array}$ & $\begin{array}{c}\text { Chicken } \\
\text { (no) }\end{array}$ \\
\hline PV & 1.5 & 1.06 & 1.36 & .60 & .23 & 8.5 & 2.9 \\
\hline $\mathrm{CV}$ & .76 & .33 & .66 & .33 & .03 & 4.3 & 9 \\
\hline
\end{tabular}

Source; household survey 2008

\section{Trees on farmland}

Average fodder trees numbers were greater in PV than that of control village due to adoption of agroforestry system in their respective farm land. On the contrary, CV holds drastically small number of fodder trees in their private farmland compared to PV farmland. However, the number fodder trees in low land (khet) of both PV (52) and CV (44) were almost similar. This is because land holding size (khet) was greater in CV where fodder trees were naturally grown since past decades. Fodder trees raised by farmers in PV were Bakino, Nimaro, Gogen, Epil Epil, Badhar, Tanki etc. Study showed that there was a significant difference in the number of fodder trees in upland (pakho) and pasture land (kharbari) of PV and CV farmlands as shown in table 8. Availability of excess fodder in PV was a pulling factor to rear more livestock in PV household.

Table 8: Number and types of trees on farmland

\begin{tabular}{|l|l|l|l|l|l|}
\hline \multicolumn{1}{|c|}{ Village } & Khet(FTN) & $\begin{array}{l}\text { Pakho } \\
\text { (FTN) }\end{array}$ & $\begin{array}{l}\text { Kharbari } \\
\text { (FTN) }\end{array}$ & \multicolumn{1}{|c|}{ FN } & FATN \\
\hline PV & 52 & 136 & 115 & 36 & 18 \\
\hline CV & 44 & 26 & 17 & 10 & 13 \\
\hline Variation (PV-CV) & 8 & $110^{*}$ & $98 * *$ & 26 & 5 \\
\hline
\end{tabular}

Source; household survey 2008

Note: $*_{\mathrm{t}}$ is significantly different at 0.05 level and $* *_{\mathrm{t}}$ is significantly different at 0.01 level FTN= fodder trees number, FN= Fruits number, FATN= fuel wood and timber numbers 


\section{Fodder Availability}

There are three general sources of fodder supply in the study area viz. Forest, pasture land and private farmland. Among three resources; 59\% of fodder was supplied through farmland whereas $6 \%$ and 35\% were contributed from forest and pasture (kharbari) respectively in PV. Results showed that supply of fodder from respective farmland of PV (500 bhari) and CV (150 bhari) household varies significantly. This is the reason of artificial plantation of fodder tree on the private farmland of PV household existing farm. Study disclosed that CV household depends more on forest for fodder which is the emerging case of forest degradation and deforestation on the site. More quantity of fuel wood and fodder was consumed by PV household as compared to CV household which may be the reason of increased livestock in the PV village as shown in the table 7 above. Thus, it implies that domestication of fodder trees on the private farmland minimizes the natural forest degradation and at the same time increases the number of livestock per household which is known for sustainable source of income in the study area.

Table 9: Supply and demand of fodder by village

\begin{tabular}{|l|l|c|c|c|l|}
\hline \multirow{2}{*}{ Sources } & \multicolumn{2}{|c|}{ Project village (PV) } & \multicolumn{2}{c|}{ Control village (PV) } & \multirow{2}{*}{$\begin{array}{c}\text { Variation } \\
\text { (PV-CV) }\end{array}$} \\
\cline { 2 - 5 } & \multicolumn{1}{|c|}{ Average bhari } & Percentage & Average bhari & Percentage & \\
\hline Farmland & 500 & 59 & 150 & 50 & $350^{* *}$ \\
\hline Forest & 50 & 6 & 120 & 40 & -70 \\
\hline Kharbari & 300 & 35 & 30 & 10 & $270^{*}$ \\
\hline Total & $\mathbf{8 5 0}$ & $\mathbf{1 0 0}$ & $\mathbf{3 0 0}$ & $\mathbf{1 0 0}$ & $\mathbf{5 5 0}$ \\
\hline
\end{tabular}

Source: Field survey, 2008

Note: ${ }^{*} t$ is significantly different at 0.05 level and $* * t$ is significantly different at 0.01 level

1 bhari $=\sim 50 \mathrm{~kg}$

\section{Income from livestock products}

Average buffalo and cattle milk production was greater in PV i.e. 1846 and 586 litres respectively compared to control village. It was clear that livestock size (large cattle) was higher in PV which can be the reason of abundant fodder supply via agroforestry practices on private farmland. Higher census of cattle on the study area leads to more milk and milk products production in the individual PV households thereby fetching higher price as shown in the table 10 below. Thus the study revealed that there was a significant difference in the milk production and income status derived from the livestock (large cattle) in PV and $\mathrm{CV}$ villages. However, the result showed that income derived from chicken and eggs was more in $\mathrm{CV}$. 
Table 10: Income from livestock production and source of income by village

\begin{tabular}{|l|l|l|l|l|l|l|l|l|l|l|}
\hline Village & MP(lit) & CMP(lit) & QMS(lit) & IMS(Rs) & QGS(N) & IGS(Rs) & QO(N) & IOL(Rs) & IMP(Rs) & CE(Rs) \\
\hline PV & 1846 & 586 & 1016 & 25416 & 1.53 & 13507 & .40 & 4083 & 4643 & 790 \\
\hline CV & 905 & 303 & 253 & 6465 & .70 & 3670 & .10 & 800 & 2523 & 2803 \\
\hline PV-CV & $941^{*}$ & 283 & 763 & $18951^{* *}$ & 0.83 & $9837 * *$ & .30 & 3283 & 2120 & -2013 \\
\hline & & & & & & & & & & \\
\hline
\end{tabular}

Source: household survey 2008

Note: *t is significantly different at 0.05 level and ** is significantly different at 0.01 level

BMP-Buffalo milk production, CMP-cow milk production, QMS-quantity milk sale, IMS-income from milk sale, QGS-quantity goat sale, IGS-income from goat sale, QO-quantity of livestock other than above, IOL-income from other livestock, IMP-income from milk product, CE-income from chicken and egg, $N$-number of livestock., $R$ s= nepali rupees

\section{Income from agroforestry components by villages}

Farm products (fruits, vegetables, fodder and fuel wood) were considered as a main source of income after livestock in the study area. Fruits and vegetables are considered as a cash generating crops. NAF had supported fruits, grasses and fodder seeds and seedling in the household of project village. Total income derived from fruits, grasses and fuel wood in PV was significantly higher compared to CV household. On the contrary, income from sale of vegetables was found more in CV (NPR 5970) compared to PV (NPR 4553) household. Fuel wood from PV villages is sold to nearby market especially in hotels and also to the nearby villagers. To sum up, income from fuel wood was significantly higher compared to other sources.

Table 11: Income from fruits, vegetables, grasses, fodder and fuel wood

\begin{tabular}{|l|l|l|l|l|l|l|l|l|l|}
\hline \multicolumn{1}{|c|}{ Village } & FTN & FI(Rs) & VI(Rs) & QGS(no) & GI(Rs) & QF(no) & IF(Rs) & QFW(no) & IFW(Rs) \\
\hline PV & 36 & 3820 & 4553 & 20 & 1000 & 51 & 3570 & 128 & 12800 \\
\hline CV & 10 & 1130 & 5970 & 4 & 200 & 8 & 560 & 27 & 2700 \\
\hline PV-CV & 26 & 2690 & -1417 & 16 & 800 & 43 & 3010 & 101 & $10100^{*}$ \\
\hline
\end{tabular}

Source: Household survey, 2008

Note: *t is significantly difference at 0.05 level

FTN-fruit trees number, FI-fruit income, VI-vegetable income, QGS-Quantity grass sale in bhari, GIgrass income in rupees, QF-quantity fodder sale in bhari, IF-income from fodder, QFD-quantity of fuel wood sold in bari, IFW-fuel wood income.

\section{Gender contribution in marketing farm products}

In PV, 64\% of the households comprises both men and women participation in marketing the products whereas only $27 \%$ in control village. Thus the results divulged that there was a significant difference in gender involvement in the villages. From the empirical results shown in table 12; it can be concluded that both male and female are engaged equally in collecting, storing and marketing agroforestry products in PV whereas in case of CV, women are more involved in farming systems. 
Table 12. Gender participation involved in selling agro forestry products

\begin{tabular}{|l|l|l|l|}
\hline \multicolumn{1}{|c|}{ Marketing of products } & \multicolumn{1}{c|}{ PV } & \multicolumn{1}{c|}{ CV } & \multicolumn{1}{c|}{ Total } \\
\hline Men & $7(23)$ & $9(29)$ & 16 \\
\hline Women & $4(13)$ & $13(43)$ & 17 \\
\hline Both & $19 *(64)$ & $8 *(27)$ & 27 \\
\hline Total & 30 & 30 & 60 \\
\hline
\end{tabular}

Source: Household survey, 2008

Note: $* \mathrm{t}$ is significantly difference at 0.05 level

Figures inside parenthesis indicates percentage

\section{Conclusion}

Agro-forestry is the land use science, which deals with the interactions between trees, crops, and of both with animals in the same unit of land. The study showed that the control village were facing a shortage of firewood and fodder due to heavy pressure of grazing on forest and community lands. After project intervention fodder and fuel wood supply has increased in farmland and as a result forest condition has improved. Agro forestry system practiced in project area, income analysis showed that project farms are more profitable than control farms. Income from sale of livestock, fruits, milk and milk products was higher in project village as compared to control village whereas income from public services, wage labour was somehow same. The vast differences in income level between two villages found mainly because of agro forestry practices adopted and not adopted. Effective agro forestry program implementation, assured higher degree of success to achieve the program goal. The agro forestry program implementation through small home nursery approach was much more effective than that of community nursery approach. It can be concluded that the agroforestry project has no harmful environmental impacts and at the same time this practices had been successful in meeting food requirement month of rural household to greater extent. 


\section{References}

Dhakal, A. 2008. Silviculture and productivity of five economically important timber species of central terai of Nepal, ITTO, Japan and NAF, Nepal, Binayak Offset Press, Kathmandu

Neupane, R. P. 2000. Prospects of Agroforestry promotion in the hills of Nepal

Pandit, B.H. 1994. Evaluation of an NGO Supported Agroforestry Program: Nepal Agroforestry Foundation Program in Kunwari Village of Ramechhap District of Nepal, Master thesis, AIT-1994.

Pandit et al. 2007. The development of sustainable livestock production systems in the Mid hills of Nepal, Based on Agroforestry concepts.

Sanchez. 1997. Trees, Soils, and Food Security. Philosophical Transactions of the Royal Society of London series.

Tustin, J.R., Knowles, R.L. and Klomp, B.K. 1979. Forest farming: a multiple land-use production system in New Zealand Forest Ecology and Management. 2:169-189

Wood, P.J. 1990. The scope and potential of agroforestry. Outlook on Agriculture. 19:14114 